\title{
MODIFIED MESRI CREEP MODELLING OF SOFT CLAYS IN THE COASTAL AREA OF TIANJIN (CHINA)
}

\author{
Ying Zhai, Yuanzhan Wang, Yanhe Dong
}

Original scientific paper

The nonlinear creep characteristics of typical clays in the coastal area of Tianjin were studied by consolidated-undrained triaxial creep tests. The tests were performed via the stepwise loading method, and the creep curves of the soft clays under different stress states were obtained from the raw data processed by Chen and Kang's method. The experiments showed that the long-term deformation of soft clays can be divided into two stages, that is, the deformation produced by increasing stress and the deformation produced by a constant load. By analysing the test data, a modified Mesri model was established based on the classical Mesri creep model, which treated the final strain of the first-stage soil deformation as the initial strain and described the second-stage soil deformation using a combination of a stress-strain hyperbolic function and strain-time hyperbolic function. The modified model contains four parameters; all of the parameters have clear physical significance and can be determined by experiment. Verification indicated that the calculated results were in good agreement with the experimental ones. For further verification, the model was applied to the calculation of the long-term settlement in the coastal area of Tianjin. The results showed that the modified model can predict the long-term creep deformation of soft clays with a satisfactory accuracy.

Keywords: coastal area of Tianjin; modified Mesri model; soft clay; creep; triaxial creep test

Modificirano Mesri modeliranje puzanja mekih glina u obalnom području Tianjina (Kina)

Izvorni znanstveni članak

Karakteristike nelinearnog puzanja tipičnih glina obalnog područja Tianjina analizirane su konsolidiranim-nedreniranim troosnim provjerama puzanjem. Provjere su izvedene stepwise metodom opterećenja, a krivulje puzanja mekih glina pod različitim stanjima naprezanja dobivene su iz podataka obrađenih Chen i Kang metodom. Eksperimenti su pokazali da se dugotrajna deformacija mekih glina može podijeliti na dvije faze, deformaciju dobivenu povećanjem naprezanja i deformaciju dobivenu konstantnim opterećenjem. Analizom podataka provjere postavljen je modificirani Mesri model temeljen na klasičnom Mesri modelu puzanja koji je tretirao finalno naprezanje deformacije tla prvog stupnja kao početno naprezanje i opisao deformaciju tla drugog stupnja primjenom kombinacije hiperboličke funkcije naprezanje-izduženje i hiperboličke funkcije izduženje-vrijeme. Modificirani model sadrži četiri parametra; svi parametri imaju jasno fizikalno značenje i mogu se odrediti eksperimentom. Provjera je pokazala da se rezultati dobiveni proračunom dobro slažu s eksperimentalnima. Zbog daljnje provjere model se primijenio u proračunu dugoročnog naselja u obalnom području Tianjina. Rezultati su pokazali da se modificiranim modelom može uz zadovoljavajuću točnost predvidjeti dugotrajna deformacija mekih glina uslijed puzanja.

Ključne riječi: meka glina; modificirani Mesri model; obalno područje Tianjina; puzanje; troosna provjera puzanjem

\section{Introduction}

With the characteristics of low strength, high compressibility, low permeability and high sensitivity, the soft clay often exhibits creep deformation, i.e., deformation behaviour under constant effective stress. The continuous deformation and failure that occur after the completion of a construction project may be caused by soil creep $[1 \div 3]$. In the creep process, viscous deformation and elastoplastic deformation occur simultaneously, which makes the soil have visco-elastoplastic characteristics. It is precisely this feature that results in the continuous deformation of soil. The creep property of soil has led to the large displacement of numerous ports and offshore structures built off of soft-clay coasts, posing an enormous threat to structural stability. For instance, due to soil creep on the soft-clay bank slope, large relative displacements between pile caps and superstructures in recent years have occurred on some corners of piled wharf in Tianjin Port, which has resulted in an inadequate seated length of beams, placing wharf structures in danger [4]. Hence, in order to avoid or control the engineering geological disaster caused by soft-clay creep, it is indispensable to carry out the study on the creep test of the soft clay and set up a suitable creep model.

Research on soft-clay creep properties has resulted in some advancements in recent years. Yin et al. [5] developed an anisotropic visco-elastoplastic soft-clay model based on Perzyna's Overstressing Theory and then validated the model using a creep test with constant strain rate. Leoni et al. [6, 7] proposed an anisotropic model for time-dependent behaviour of soft soils assuming rotated Modified Cam Clay ellipses as contours of volumetric creep strain rates, and then performed several validation tests to assess the capability of the model. Kelln et al. [8] revealed the creep behaviour of soft clays using viscoelastic mechanics. Luo et al. [9] performed a series of tests to investigate the creep characteristics of soft soil in interactive marine and terrestrial deposits of the Pearl River Delta, and they demonstrated that triaxial creep features were closely associated with the drainage conditions and consolidation could weaken the effect of creep.

Scholars have dedicated great efforts to studying the soft-clay creep problem in the coastal area of Tianjin. Wang et al. [10] studied the creep deformation law of muddy soft clays in the coastal area of Tianjin in terms of yield theory and established a nonlinear rheological constitutive model of the coastal soft clays. Tian et al. [11] described the creep characteristics of typical soft clays in Tianjin Port combining the triaxial creep test and Singh-Mitchell's model. Yan et al. [12] performed an unconsolidated-undrained triaxial creep test using undisturbed samples with large diameters, and then established a no-yield-surface model to simulate the creep of foundation soils in the coastal area of Tianjin. Wang et al. [13] fitted curves based on the results of triaxial creep tests using the Merchant creep model and built a creep model for the soft clay in the Tianjin littoral area. 
The use of soil creep models has led to many contributions to soil science. However, these models are not sufficient to fully explain the creep properties of soft clays in the coastal area of Tianjin. The main reason of this research gap is that creep strain presents different non-linear characteristics for different types of soft clays, there is a problem associated with the adaptability of the creep model itself. For example, when fitting the creep curves of typical clay in Tianjin using Singh-Mitchell model, large errors may occur at the later stage, especially under high pressure [11]. Large errors may also occur when fitting creep curves with the Merchant model under high stress [13]. Creep models with nonlinear elements can pinpoint creep along certain stress paths. However, this ability is not convenient to extend to engineering because of the massive parameters and complex theory involved in the models.

This paper presents a study on the creep behaviour of soft clays in the coastal area of Tianjin through a series of consolidated-undrained triaxial tests. Based on the classic Mesri empirical model proposed by Masri et al. [14], a modified Mesri model with four parameters was established, which was then verified for the effectiveness and applicability by test data. The proposed model can be applied to calculating the long-term settlement of important structures in the actual projects, meanwhile some methods and ideas may be provided for other soft clays in different regions.

\section{Triaxial creep test}

\subsection{Test apparatus and samples}

The test equipment is the SLB-1 triaxial shear and permeability apparatus with stress-strain control. The instrument is a type of multifunction flexible triaxial test apparatus which can perform unconsolidated- undrained test (UU), consolidated-undrained test (CU) and consolidated-drained (CD) test as well as some other tests such as anisotropic consolidation, isotropic consolidation, backpressure saturation, $K_{0}$ test and triaxial creep test. Every unit of the apparatus is controlled by microprocessor and it not only can be operated independently, but can conduct data exchange with computer and data acquisition processing as well. The axial load capacity can reach $20 \mathrm{kN}$, and the confining pressure ranges from 0 to $1,99 \mathrm{MPa}$. The measurement accuracy is controlled to within $1 \%$.

With a diameter of $39,1 \mathrm{~mm}$ and a height of $80 \mathrm{~mm}$, test samples used in the study were remoulded clay drilled from the $5 \div 10 \mathrm{~m}$ soil layer in the Tianjin Port area. The physical properties of the soil samples are shown in Tab. 1 .

Table 1 Basic physical parameters of soil samples

\begin{tabular}{|c|c|c|c|c|}
\hline $\begin{array}{c}\text { Density } \gamma / \\
\left(\mathrm{kN} / \mathrm{m}^{3}\right)\end{array}$ & $\begin{array}{c}\text { Moisture } \\
\text { content } \omega / \%\end{array}$ & $\begin{array}{c}\text { Dry density } \\
\gamma_{\mathrm{d}} /\left(\mathrm{kN} / \mathrm{m}^{3}\right)\end{array}$ & $\begin{array}{c}\text { Saturation } \\
\mathrm{Sr} / \%\end{array}$ & $\begin{array}{c}\text { Void } \\
\text { ration } e\end{array}$ \\
\hline 18,201 & 45,62 & 12,499 & 100 & 1,316 \\
\hline
\end{tabular}

\subsection{Test method}

Two different types of loading methods can be employed in a creep test, the separately loading method and the stepwise loading method. For the separately loading method, it is assumed that some identical specimens are taken from the same soil and the tests are carried out at the same time under conditions of identical instruments and different stress levels. This method can theoretically meet the needs of rheological test under the desired conditions and can even directly obtain the rheological curve of the test soil, however, due to the difficulty in ensuring the same condition between tests and in deploying a large number of instruments to perform creep tests over a long period, it is not easy to perform strictly separate loading [15]. For the stepwise loading method, the stress at different levels is applied to a sample step by step. This method requires fewer soil samples and fewer instruments, which is easy to perform, and overcomes the limits of the separately loading method. Moreover, the method can reduce the discreteness of the test results for different samples. Therefore, the stepwise loading method was adopted in this study. Considering the poor permeability of soft clay, the undrained triaxial creep test was adopted. Depending on the soil depth, the confining pressure was $50 \mathrm{kPa}, 100$ $\mathrm{kPa}$ or $150 \mathrm{kPa}$.

Table 2 Scheme of step loading

\begin{tabular}{|c|c|c|c|c|c|c|}
\hline \multirow{2}{*}{ Soil property } & \multirow{2}{*}{$\sigma_{3} / \mathrm{kPa}$} & \multicolumn{5}{|c|}{$\left(\sigma_{1}-\sigma_{3}\right) / \mathrm{kPa}$} \\
\cline { 3 - 7 } & & Level 1 & Level 2 & Level 3 & Level 4 & Level 5 \\
\hline \multirow{3}{*}{ Muddy clay } & 50 & 14 & 28 & 42 & 56 & 66 \\
\cline { 2 - 7 } & 100 & 25 & 50 & 75 & 100 & 115 \\
\cline { 2 - 7 } & 150 & 35 & 70 & 105 & 140 & 175 \\
\hline
\end{tabular}

The test procedure was as follows: (1) A consolidated undrained triaxial test was conducted on the soil samples under confining pressures of $50 \mathrm{kPa}, 100 \mathrm{kPa}$ and 150 $\mathrm{kPa}$. The experimental results showed that the deviatoric stress at failure $\left(\sigma_{1}-\sigma_{3}\right)_{f}$ (when the axial strain reached $15 \%$ ) at the different confining pressures was $70,2 \mathrm{kPa}$, $120,5 \mathrm{kPa}$ and $178,8 \mathrm{kPa}$, respectively. (2) The deviatoric stress level was determined by $\left(\sigma_{1}-\sigma_{3}\right)_{f}$. In this test, five loading levels were adopted and the loading scheme is shown in Tab. 2. (3) The samples were saturated using vacuum saturation method. The pore water pressure coefficient B-value was measured to confirm the saturation until it reaches $98 \%$. (4). The samples were isotropically consolidated for 24 hours due to the poor permeability of clay. (5) Loading was performed on the sample step by step under undrained conditions. The loading time for each level was 48 hours.

\subsection{Test results}

\subsubsection{The method of data processing}

In this paper, Chen and Kang's method [16] was used to process the stepwise loading data. Chen and Kang's method can be summarized as follows: 
The step load with the increment of $\Delta \sigma_{\mathrm{i}}$ in each step is applied on the soil sample shown in Fig. 1(a), and the strain-time curves are obtained in Fig. 1(b). From $t=0$ to $t=t_{1}$, the first level load $\Delta \sigma_{1}$ is applied on the soil sample and the creep reached a steady state. If the next level load $\Delta \sigma_{2}$ is not applied subsequently, the deformation will develop along the dotted line due to the steady state creep. Therefore, the effect of the second level load $\Delta \sigma_{2}$ is leading to additional deformation between the dotted line and the solid line. The additional deformation is added to the deformation caused by the first level load $\Delta \sigma_{1}$ from $t=$ 0 to $t=t_{1}$, which is considered as the deformation caused by the load $\Delta \sigma_{1}+\Delta \sigma_{2}$ from $t=0$ to $t=t_{1}$. The same method is used under other load, then the strain-time creep curves under different stress stages can be obtained.
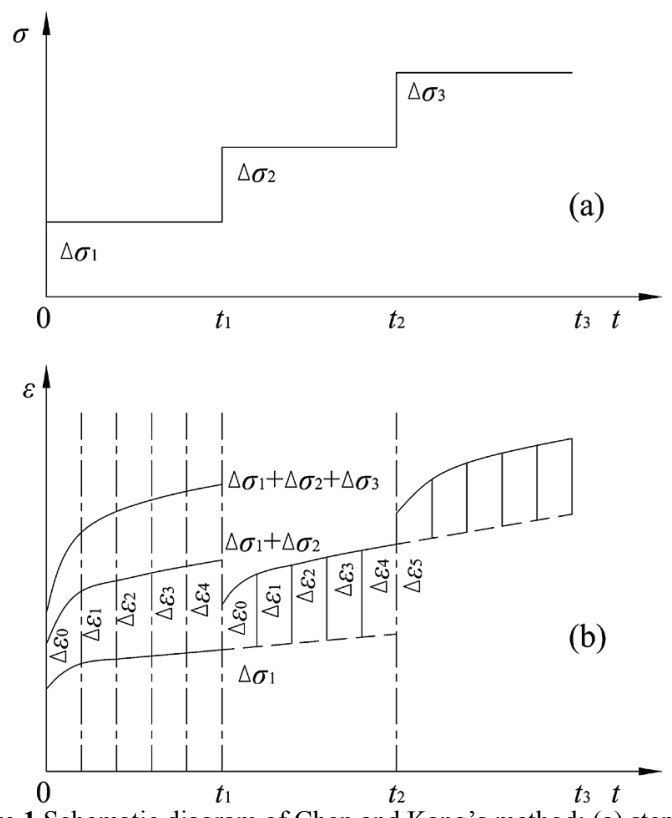

Figure 1 Schematic diagram of Chen and Kang's method: (a) step load, (b) nonlinear superposition of the deformation

\subsubsection{Discussion of the results}

(1) The axial strain-time curve is shown in Fig. 2. The deformation presented an attenuation-steady state process before the deviator stress reaches the deviatoric stress at failure. With the increase of deviator stress, the strain of the specimen increased significantly. Under low-stress levels, the strain clearly revealed a trend of attenuation creep, and the creep phenomenon was not distinct; while under high-stress levels, the creep curve consisted of obvious attenuation and steady state stages, and the slope of the curve in the steady state stage increased with the increase of deviator stress. No significant constant-rate creep is observed before the damage of the sample.

(2) The logarithmic strain-logarithmic time curve is shown in Fig. 3. The double logarithm curves presented a linear relationship and the curves are almost parallel with each other at different deviator stress levels. The linear relationship of the double logarithm curve was slightly worse when the deviator stress was close to the deviatoric stress at failure.

(3) The strain rate-time curve is shown in Fig.4. Under each stress level, the strain rate decreased over time and went to zero asymptotically. Moreover, the strain rate increased with the deviatoric stress.

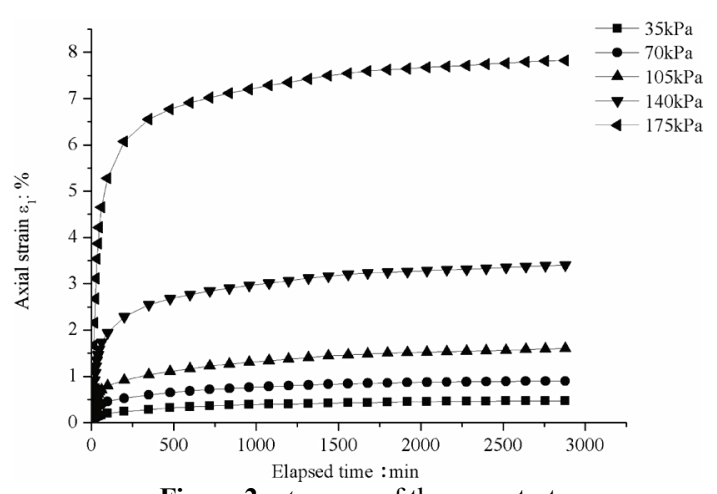

Figure $2 \varepsilon$ - $t$ curves of the creep test

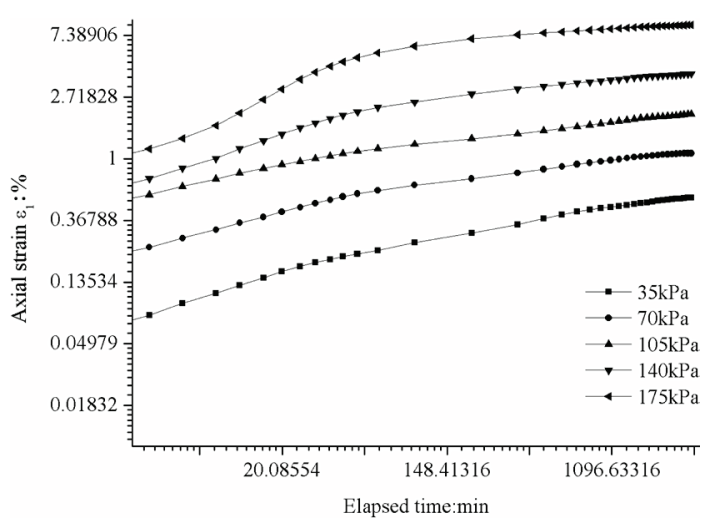

Figure 3 Relationship between $\ln \varepsilon$ and $\ln t$

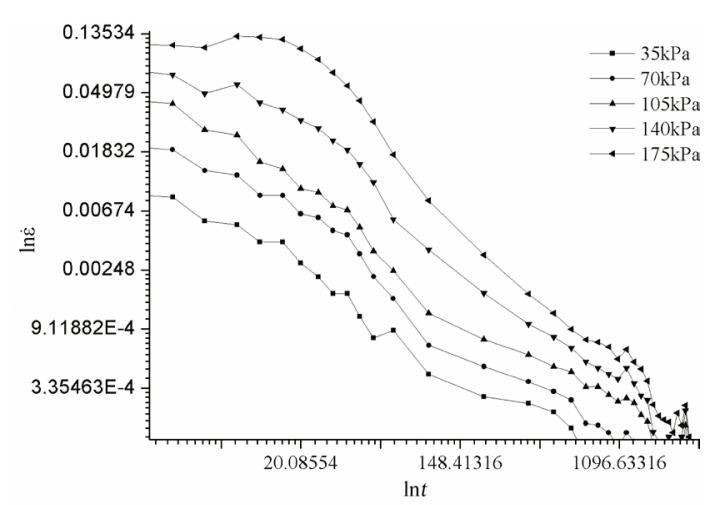

Figure 4 Relationship between $\ln \dot{\varepsilon}$ and $\ln t$

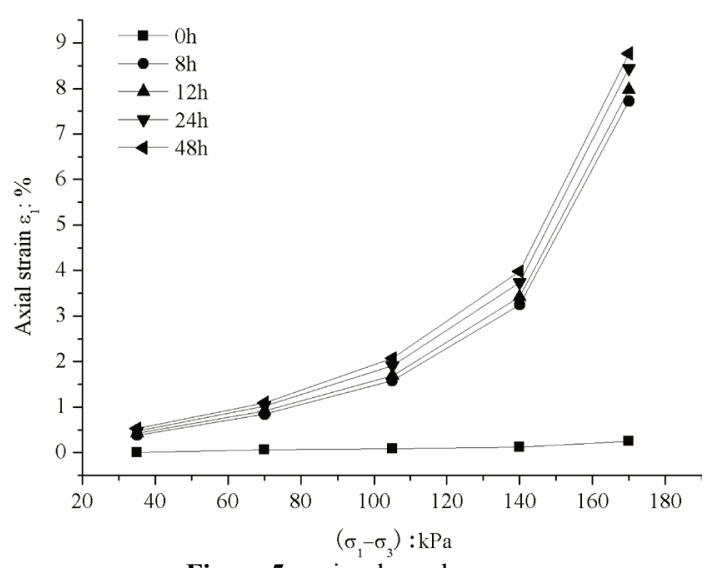

Figure $5 \sigma-\varepsilon$ isochronal curves

(4) The stress-strain curve is shown in Fig. 5. The relationship between stress and strain was linear at the initial time $t=0$ (when the load was applied gradually), 
while after the load was steady, it presented a distinctly nonlinear behaviour and the stress-strain curves were similar at different moments. Thus all of the curves can be described by a unified function, except for that representing the initial moment.

\section{Empirical creep model}

The creep model of soil can be sorted into a component model, endochronic model, yield surface model and empirical model [17]. Among them, the element model is not applicable to describe the nonlinear creep property of soft soil; the endochronic model and the yield surface model describe the creep properties of soft soil based on the essence of stress. However, both models are relatively complex and involve a large number of parameters. The empirical model, although lacking rigorous theoretical basis compared with the endochronic model and the yield surface model, could often obtain a good fitting result using a small number of parameters. Therefore, it has been applied widely in many geotechnical engineering.

The empirical nonlinear creep model of soil is based on flow theory and aging theory. Its stress-strain-time relationship can be obtained completely based on creep test results. The creep equation features two terms - a deformation function (stress-strain relationship) and a creep function (strain-time relationship). The stress-strain relationship can be represented by a power function or hyperbolic function, while the strain-time relationship can be represented by a power function, logarithmic function, exponential function or hyperbolic function [18].

\subsection{Deformation function (stress-strain relationship)}

The Singh-Mitchell equation [19] and the Mesri equation [14] are two famous types of empirical nonlinear creep models. The stress-strain relationships in these models are exponential functions and hyperbolic functions, respectively.

When the unit time is taken, the stress-strain relationship of the Singh-Mitchell equation can be written as

$$
\varepsilon=B_{1} \exp \left(\beta D_{r}\right)
$$

where $D_{r}$ is the deviatoric stress level $\left(\sigma_{1}-\sigma_{3}\right) /\left(\sigma_{1}-\sigma_{3}\right)_{f}$, and $\left(\sigma_{1}-\sigma_{3}\right)_{f}$ is the deviatoric stress at failure, which can be obtained by the undrained triaxial compression test; $B_{1}$ and $\beta$ are the parameters and can be obtained from a plot of $\ln \varepsilon$ against $D_{r}$.

When the unit time is taken, the stress-strain relationship of the Mesri equation can be written as

$$
\varepsilon=\frac{2}{E_{u} / S_{u}} \frac{D_{r}}{1-R_{f} D_{r}}
$$

where $E_{u}$ is the tangent modulus; $S_{u}=1 / 2\left(\sigma_{1}-\sigma_{3}\right) ; 2 /\left(E_{u} / S_{u}\right)$ is the reference strain, which can be defined as a parameter; $R_{f}$ is the fitting ratio. $2 /\left(E_{u} / S_{u}\right)$ and $R_{f}$ can be obtained from a plot of $\varepsilon / D_{r}$ against $\varepsilon$.
The test data under a confining pressure of $150 \mathrm{kPa}$ is taken as an example to illustrate both models. The unit time is taken as $1 \mathrm{~d}$. It can be observed from the plot of $\ln \varepsilon$ against $D_{\mathrm{r}}$ shown in Fig. 6 that the measured data presents a linear relationship in the middle period of the deviatoric stress level. However, the curve appears nonlinear when the deviatoric stress approaches 1 or 0 . An exponential function can only describe the stress-strain relationship when the deviatoric stress level is in the middle period (ranging from $20 \div 80 \%$ ). In contrast, a hyperbolic function can accurately describe all stress levels. Therefore, the hyperbolic function is adopted to describe the stress-strain relationship in the proposed model.

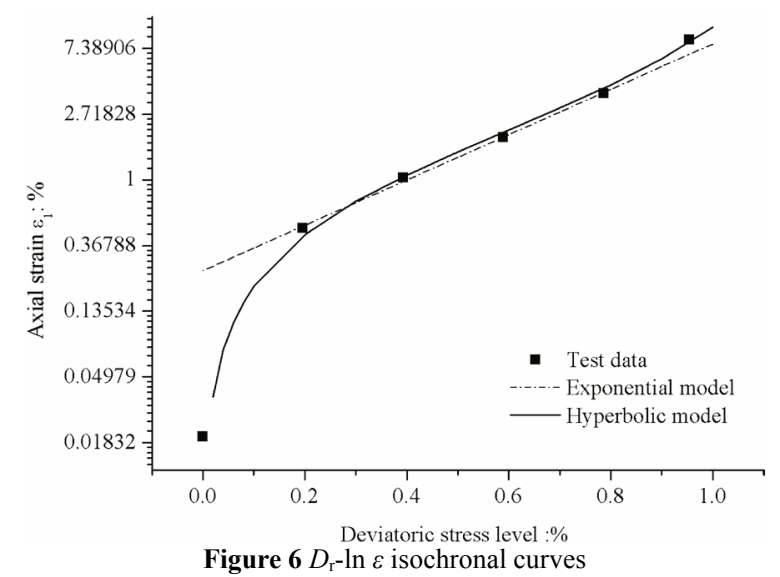

\subsection{Creep function (strain-time relationship)}

In the classic Mesri model, the strain-time relationship is described by a power function, which can be expressed as

$$
\varepsilon=\frac{2}{E_{u} / S_{u}} \frac{D_{r}}{1-R_{f} D_{r}}\left(\frac{t}{t_{1}}\right)^{\lambda}
$$

The model contains three parameters: the reference strain $2 /\left(E_{u} / S_{u}\right)$, the fitting ratio $R_{f}$ and the creep parameter $\lambda$ where $2 /\left(E_{u} / S_{u}\right)$ and $R_{f}$ can be determined by the method described above, and $\lambda$ is the slope of the $\ln \varepsilon-\ln t$ curve shown in Fig. 3. Finally, the creep curve, which is fitted by the classic Mesri model, is shown in Fig. 7.

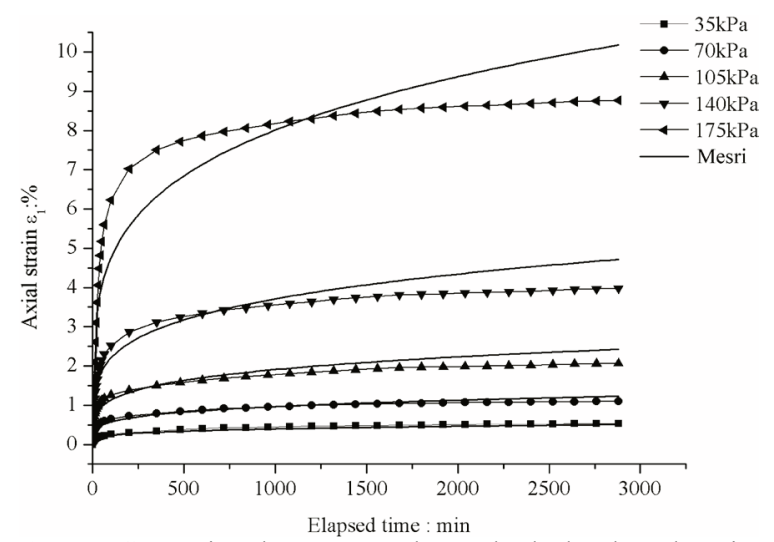

Figure 7 Comparison between test data and calculated results using Mesri's model 
The fitting result clearly showed that the strain increases continuously with time and a steady state stage may not be obtained when a power function was chosen for the strain-time relationship. Compared with the test curve, the fitting curve had a slower creep speed in the early stage and a faster creep speed in the late stage. Moreover, the fitting curve deviated significantly from the test curve in the later stage of the creep. Therefore, the classic Mesri model should be modified to improve its accuracy in modelling the creep of soft clays in the coastal area of Tianjin.

\subsection{Modified Mesri model}

It can be seen from Fig. 5 that the stress-strain isochronous curves are similar to each other except at the initial time $t=0$. A similar condition [14] for stress-strain isochronous curves is expressed as follows:

$$
\varphi(\varepsilon)=D_{r} \psi(t)
$$

where $\varphi(\varepsilon)$ is a function related to the strain and stress at any time, which can be expressed in the form of Eq. (2); $D_{r}$ is the deviatoric stress level; $\psi(t)$ is a time-dependent function and can be determined by phenomenology:

$$
\psi(t)=1+\int_{0}^{t} K(t) d t
$$

С. С. Вялов [20] put forward the following general time function expression:

$$
K(t)=\left(\frac{T_{2}}{T_{1}+t}\right)^{n}
$$

where $T_{1}, T_{2}$ and $n$ are undetermined parameters. According to attenuation-steady state creep characteristics of the test, $n=2, T_{1}=T$, and $T_{2}=[T(\delta-1)]^{1 / 2}$ are taken, where $T$ is an undetermined parameter and the time function can be expressed as

$$
\psi(t)=1+(\delta-1) \frac{t}{T+t}
$$

where $\delta$ is the creep parameter. For $A=2 /\left(E_{u} / S_{u}\right)$, writing Eq. (2) in the form $D_{r}=\varphi(\varepsilon)$ and then substituting it and Eq. (7) into Eq. (4), the following equation is obtained:

$$
\varepsilon=\frac{D_{r} A \delta(T+\delta t)}{\left(1-D_{r} R_{f}\right) \delta T+\left(1-D_{r} R_{f} \delta\right) \delta t}
$$

At $t=0$, Eq. (8) is expressed as

$$
\varepsilon_{0}^{*}=\frac{D_{r} A}{1-D_{r} R_{f}}
$$

At $t=\infty$, Eq. (8) is expressed as

$$
\varepsilon_{\infty}=\frac{D_{r} A \delta}{1-D_{r} R_{f} \delta}
$$

By substituting Eqs. (9) and (10) into Eq. (8), the following equation can be obtained:

$$
\varepsilon=\varepsilon_{0}^{*}+\left(\varepsilon_{\infty}-\varepsilon_{0}^{*}\right) \frac{t}{T^{*}+t}
$$

where $T^{*}=1 / \delta\left(\varepsilon_{\infty} / \varepsilon_{0}^{*}\right) T$. Eq. (11) is a hyperbolic function; thus, it can be used to describe the attenuation-steady state creep behaviour.

The experimental results demonstrated that the long-term deformation of soft clay could be divided into two stages: the primary stage, during which strain was produced by increasing stress, and the creep stage, during which strain was produced by a constant load. The strain-stress relation had different functional forms in the two stages. It can be seen from the stress-strain isochronal curve shown in Fig. 8 that the stress-strain relationship includes two basic types of functions. At the initial time, stress increases almost linearly with strain and the stress-strain curve can be described by the linear function $\sigma=\varphi_{0}(\varepsilon)$, but this stage is short in duration. Then the relationship between stress and strain exhibits distinctly nonlinear characteristics and the stress-strain curve can be described by the nonlinear function $\sigma=\varphi_{1}(\varepsilon)$. It can thus be inferred that the first functional form belongs to the primary stage of soft-clay deformation, and the second strictly belongs to the creep stage that is the second step of soft-clay deformation. The two stages are divided by the moment at which the stress-strain curve becomes nonlinear. The stress-strain function in the creep model is not applicable to the first stage of soft-clay deformation, so each stage should be analyzed separately. Previous empirical creep models usually take no account of the initial strain and include all of the test data in the fitting range, which generates errors.

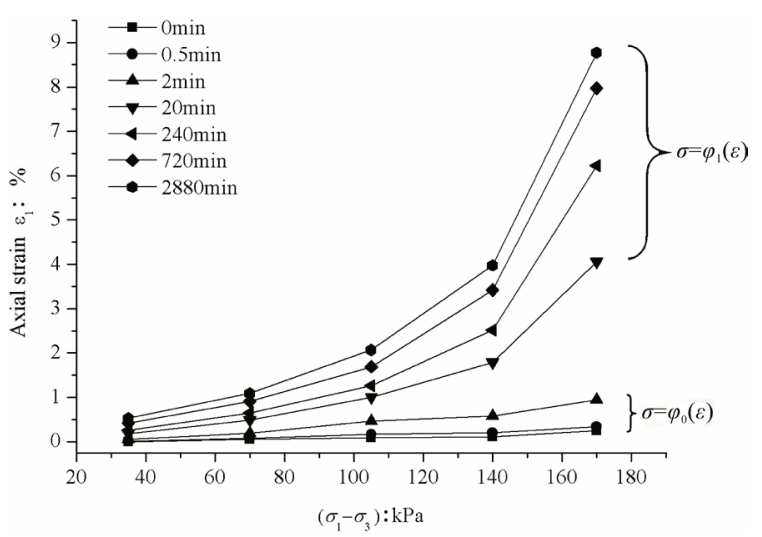

Figure 8 Analysis of the $\sigma-\varepsilon$ isochronal curves

Based on the foregoing analysis, in conjunction with the test results obtained, the time required to reach a steady state under an applied load ( $2 \mathrm{~min}$ in this test) is regarded as the cutoff point of the two stages. The strain of the cut-off point $\varepsilon_{0}$ is treated as the initial strain, and this moment is selected as time zero in the creep stage, that is

$$
\varepsilon_{\infty}-\varepsilon_{0}=\frac{2}{E_{u} / S_{u}} \frac{D_{r}}{1-R_{f} D_{r}}
$$

Thus, $\varepsilon_{0}^{*}$ and $\mathrm{t}$ in Eq. (11) are redefined, yielding the following modified Mesri empirical creep model: 


$$
\varepsilon=\varepsilon_{0}+\frac{2}{E_{u} / S_{u}} \frac{D_{r}}{1-R_{f} D_{r}} \frac{t}{t+T^{*}}
$$

The modified model contains four parameters: $\varepsilon_{0}$, $2 /\left(E_{u} / S_{u}\right), R_{f}$ and $T^{*}$ where $\varepsilon_{0}$ is the initial strain when the moment of the load is steady; $2 /\left(E_{u} / S_{u}\right)$ and $R_{f}$ are parameters of the $\left(\varepsilon_{\infty}-\varepsilon_{0}\right)-D_{\mathrm{r}}$ isochronal curve when time tends toward infinity, which have the same physical meaning as the classical Mesri model; $T^{*}$ is a creep parameter.

The methods to determine the parameters in the modified model are described as follows:

(1) Determination of parameter $\varepsilon_{0}$. According to the experimental conditions and stress-strain isochronal curve, it is set to $2 \mathrm{~min}$ from the beginning to the steady state of the load at each level. $\varepsilon_{0}$ under different deviatoric stress level is shown in Tab. 3.

(2) Determination of parameter $T^{*}$. By substituting Eq. (12) into Eq. (13), the following expression is obtain

$$
\varepsilon-\varepsilon_{0}=\left(\varepsilon_{\infty}-\varepsilon_{0}\right) \frac{t}{t+T^{*}}
$$

Let $\varepsilon_{\infty}^{*}=\varepsilon_{\infty}-\varepsilon_{0}, Y=t /\left(\varepsilon-\varepsilon_{0}\right), a=1 / \varepsilon_{\infty}^{*}$, and $b=T^{*} / \varepsilon_{\infty}^{*}$. By converting Eq. (14) to the linear form $Y=a x+b$, the $t /\left(\varepsilon-\varepsilon_{0}\right)-t$ relation can be obtained, as shown in Fig. 9. The values of $T^{*}$ under five different loads can be obtained by linear fitting.

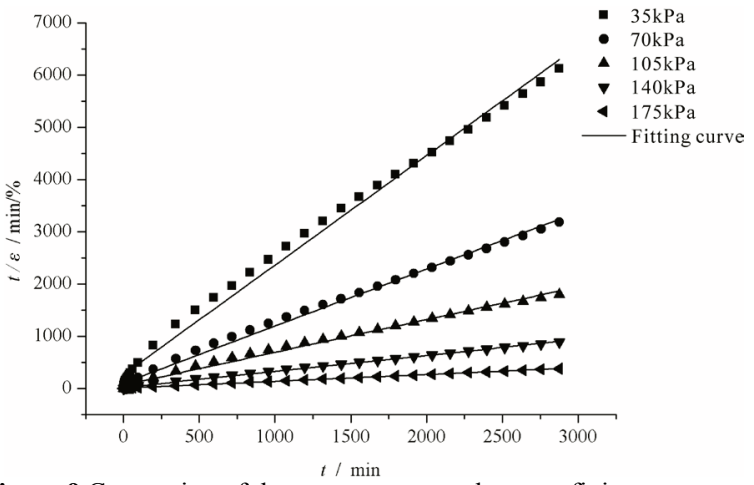

Figure 9 Conversion of the creep curves under a confining pressure of $150 \mathrm{kPa}$

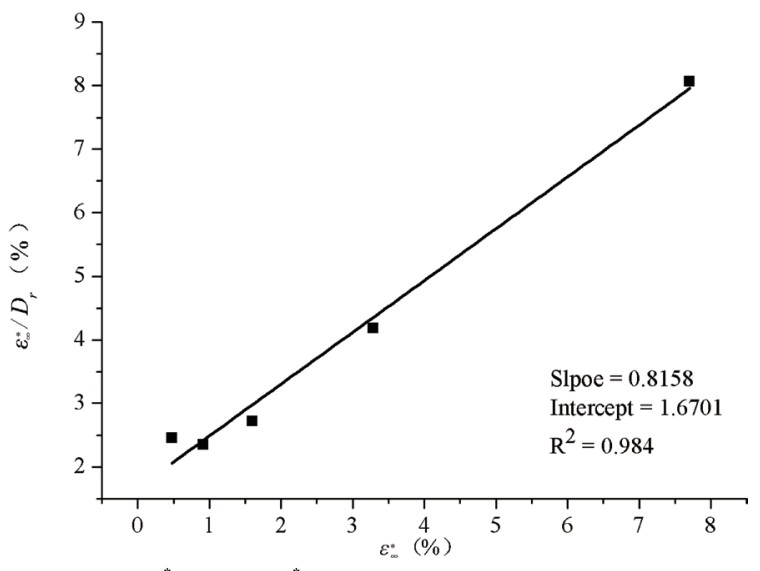

Figure $10 \varepsilon_{\infty}^{*} / D_{\mathrm{r}}$ with $\varepsilon_{\infty}^{*}$ under confining pressure of $150 \mathrm{kPa}$

(3) Determination of parameters $2 /\left(E_{u} / S_{u}\right)$ and $R_{f}$. $\varepsilon_{\infty}^{*} / D_{r}$ is plotted versus $\varepsilon_{\infty}^{*}$ according to the results described above, as shown in Fig. 10. Based on the intercept and slope of the fitted line, the two abovementioned parameters can be determined.

The creep-model parameters of saturated remodelling soft clays in Tianjin Port under different confining pressures are shown in Tab. 3.

Table 3 Values of parameters for the modified Mesri model

\begin{tabular}{|c|c|c|c|}
\hline$\sigma_{3} / \mathrm{kPa}$ & 50 & 100 & 150 \\
\hline $2 /\left(E_{u} / S_{u}\right) / \%$ & 1,7711 & 1,6643 & 1,6701 \\
\hline$R_{f}$ & 0,8544 & 0,8308 & 0,8158 \\
\hline$T($ Average $)$ & 103 & 126,94 & 96,12 \\
\hline Level1- $\varepsilon_{0} / \%$ & 0,0845 & 0,0728 & 0,061 \\
\hline Level2- $\varepsilon_{0} / \%$ & 0,3835 & 0,2923 & 0,1890 \\
\hline Level3- $\varepsilon_{0} / \%$ & 0,6823 & 0,5485 & 0,4687 \\
\hline Level4- $\varepsilon_{0} / \%$ & 1,0360 & 0,7986 & 0,5762 \\
\hline Level5- $\varepsilon_{0} / \%$ & 1,6823 & 1,1610 & 0,9473 \\
\hline
\end{tabular}

\section{Model verification}

In order to assess the capability of the modified Mesri model to predict the real behavior of soft clays in the coastal area of Tianjin, test data of both remoulded and undisturbed soft clays have been used as a benchmark.

\subsection{Remoulded soft clays}

The comparisons between the modified Mesri model and test data from chapter 2 under confining pressures of $50 \mathrm{kPa}, 100 \mathrm{kPa}$ and $150 \mathrm{kPa}$ are shown in Figs. $11 \div 13$, respectively. Good agreements are seen for most of the cases and the maximum error is less than $5 \%$. The proposed model is apparently more precise than the classical Mesri model, especially for predicting the creep behaviour during the late stage.

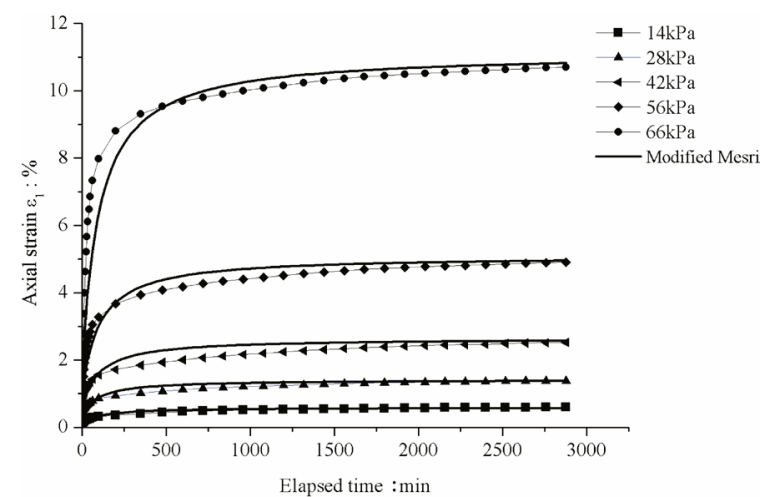

Figure 11 Fitting the creep curves under a confining pressure of $50 \mathrm{kPa}$

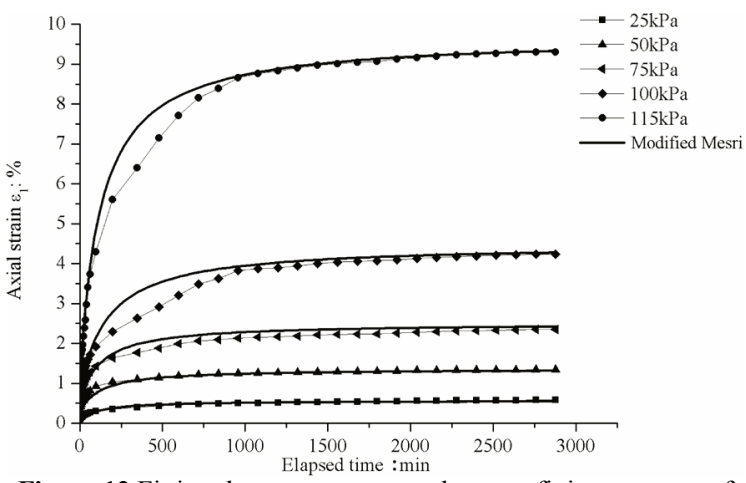

Figure 12 Fitting the creep curves under a confining pressure of $100 \mathrm{kPa}$ 


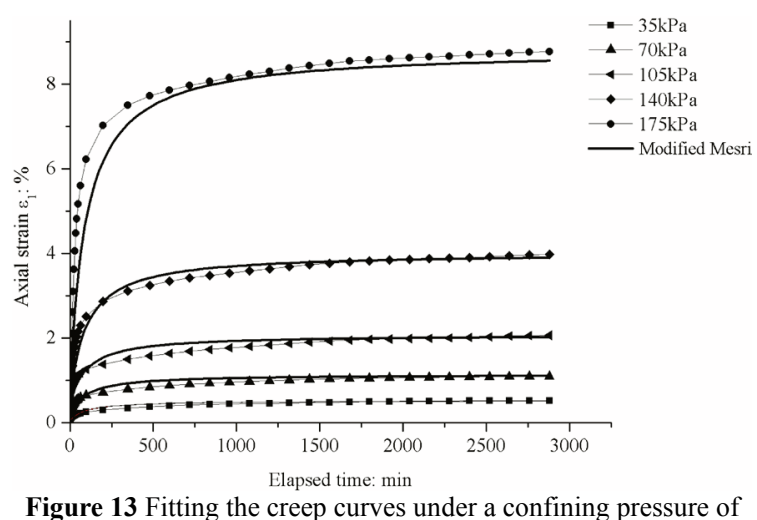

$150 \mathrm{kPa}$

\subsection{Undisturbed soft clays}

Undisturbed muddy clay and silty clay were selected from typical soft clays in the coastal area of Tianjin. Experimental data were adopted from Tian et al. [11]. The physical properties of clays are summarized in Tab. 4.

According to the soil depth, the creep test data for muddy clay under a confining pressure of $100 \mathrm{kPa}$ and for silty clay under a confining pressure of $200 \mathrm{kPa}$ were selected. Four load levels were used. For muddy clay, the levels of the deviatoric stress were $25 \mathrm{kPa}, 50 \mathrm{kPa}, 75 \mathrm{kPa}$ and $100 \mathrm{kPa}$, and the deviatoric stress at failure of the consolidated undrained (CU) test was $134,4 \mathrm{kPa}$. For silty clay, the levels of the deviatoric stress were $50 \mathrm{kPa}, 100$ $\mathrm{kPa}, 150 \mathrm{kPa}$ and $200 \mathrm{kPa}$, and the deviatoric stress at failure was $244,9 \mathrm{kPa}$.

Table 4 Basic physical parameters of the soil samples

\begin{tabular}{|l|c|c|}
\hline \multicolumn{1}{|c|}{ Clay type } & Muddy clay & Silty clay \\
\hline Depth $/ \mathrm{m}$ & $0 \sim 13$ & $13 \sim 17$ \\
\hline Moisture content $/ \%$ & 63,26 & 41,80 \\
\hline Density $/ \mathrm{g} \cdot \mathrm{cm}^{-3}$ & 1,70 & 1,84 \\
\hline Liquid limit $w_{l} / \%$ & 1,07 & 0,87 \\
\hline Plastic limit $w_{p} / \%$ & 21,39 & 18,26 \\
\hline Void ratio $e$ & 1,237 & 0,965 \\
\hline
\end{tabular}

Values of parameters for the modified Mesri model are shown in Tab. 5. The fitting curves and the measurement curves are compared in Figs. 14 and 15. For muddy clay, the modified Mesri model showed high fitting precision with respect to the test data; for silty clay, the fitting curves and the test data are largely consistent, except for the errors in the fitting results observed under the highest stress state. Additionally, the error range of the low stress can be controlled to within $5 \%$, and the maximum error under the highest stress can also be controlled to within $10 \%$.

Table 5 Values of parameters for Modified Mesri model

\begin{tabular}{|c|c|c|c|c|c|c|}
\hline Clay type & $\sigma_{3} / \mathrm{kPa}$ & $2 /\left(E_{u} / S_{u}\right) / \%$ & $R_{f}$ & $T$ (Average) & Deviatoric stress & $\varepsilon_{0} / \%$ \\
\hline \multirow{3}{*}{ Muddy clay } & \multirow{3}{*}{100} & \multirow{3}{*}{3,0599} & \multirow{3}{*}{0,405} & \multirow{3}{*}{146} & Level 1 & 0,1065 \\
\hline & & & & & Level 2 & 0,2440 \\
\hline & & & & & Level 4 & 0,4735 \\
\hline \multirow{3}{*}{ Silty clay } & \multirow{3}{*}{200} & \multirow{3}{*}{2,1676} & \multirow{3}{*}{0,063} & \multirow{3}{*}{114} & Level 1 & 0,0863 \\
\hline & & & & & Level 2 & 0,1998 \\
\hline & & & & & Level 4 & 0,3802 \\
\hline
\end{tabular}

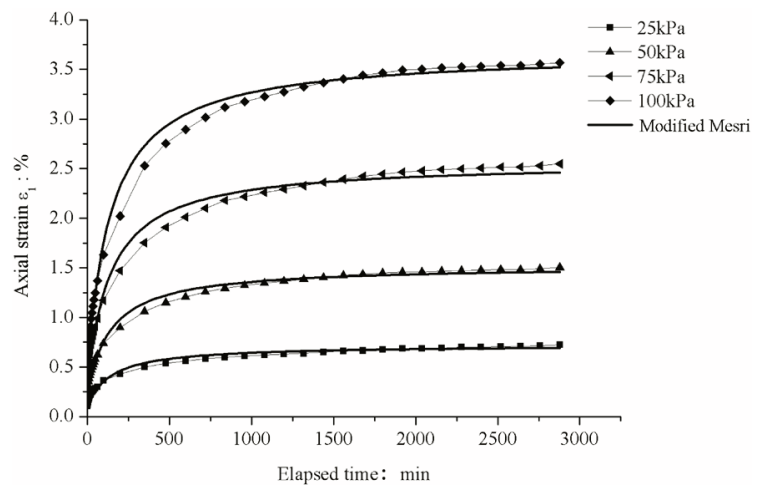

Figure 14 Fitting creep curves of the muddy clay under a confining pressure of $100 \mathrm{kPa}$

In conclusion, calculated results agree well with the test data of both remoulded and undisturbed soft clays, which provides convincing evidences for the rationality and applicability of the proposed model.

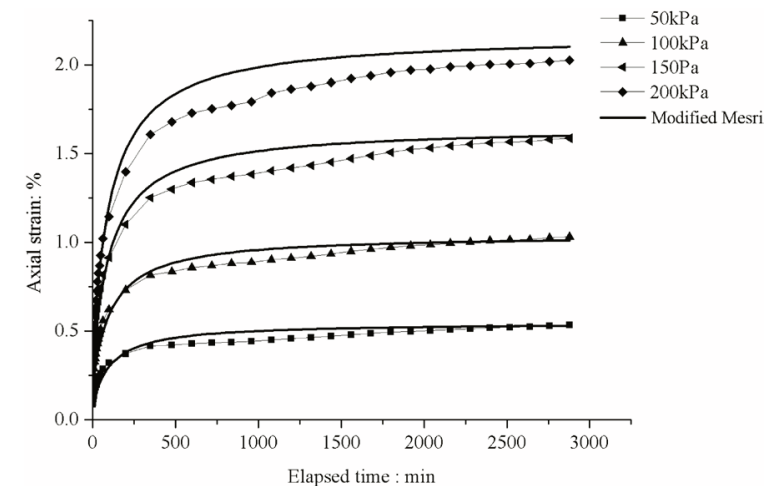

Figure 15 Fitting creep curves of the silt clay under a confining pressure of $200 \mathrm{kPa}$

\section{Application of the modified Mesri model \\ 5.1 The settlement model based on the modified Mesri creep model}

In this paper, the foundation settlement is calculated by combining the modified Mesri model with the layer-wise summation method. The formula can be expressed as follows: 


$$
\sum_{i=1}^{n} \varepsilon_{i} H_{i}=\sum_{i=1}^{n} \varepsilon_{0} H_{i}+\sum_{i=1}^{n} A \frac{D_{r i}}{1-B D_{r i}} \frac{t}{t+T} H_{i}
$$

where $D_{r i}=\left(\sigma_{1}-\sigma_{3}\right) / q_{f}$, and $D_{r i}$ is the deviatoric stress. Parameters $A, B$ and $T$ are determined by the indoor creep test. $\varepsilon_{0}$ is the instantaneous strain of loading, which can be obtained from the measured value of the initial sedimentation $\left(S_{0}=\varepsilon_{0} H\right)$; it can also be obtained by an indoor creep test. $\sigma_{1}$ is the sum of the gravity stress and the additional stress of the foundation. $\sigma_{3}=\sigma_{1} K_{0}$, and $K_{0}$ can be obtained by the indoor test or by estimating Poisson's ratio. $q_{f}$ is the value of the deviatoric stress at failure. The test results indicate that there is a linear increase in the deviatoric stress at failure with confining pressure (Fig. 16), by which different values of the deviatoric stress at failure of different soil layers can be obtained.

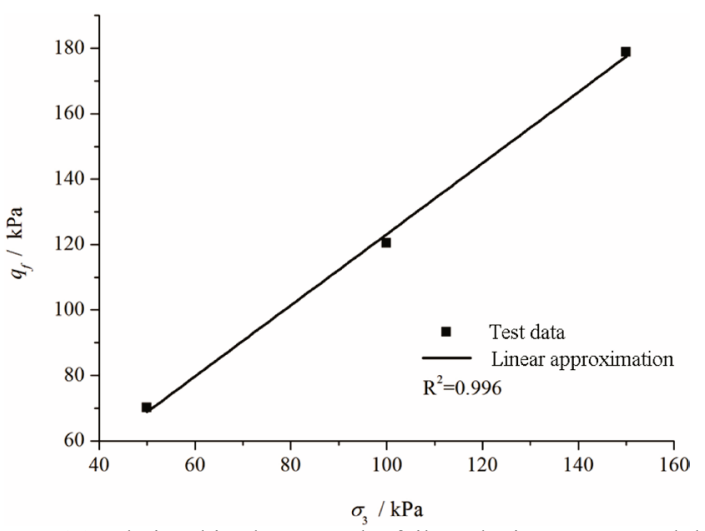

Figure 16 Relationships between the failure deviator stress and the confining pressure

\subsection{Long-term settlement in the coastal area of Tianjin}

Eighteen years ago, the Tianjin Economic Technological Development Area (TEDA) was built in Tianjin Binhai New Area, which lies along the coast. Under the effects of surcharges of large area backfill, whose thickness is $2 \mathrm{~m}$, the settlement of this area grew to be as large as $505 \mathrm{~mm}$ within 18 years $\left(t=5,68 \times 10^{8} \mathrm{~s}\right)$. However, in recent years, the sedimentation rate has attenuated.

The muddy clay layer in the coastal area of Tianjin lies between a thick silty clay layer and the layer of the backfill. Therefore, it is considered that the muddy clay maintains undrained condition in the settlement process. Based on previous research, the depth of the backfill is 2 $\mathrm{m}$, the specific weight is $17,8 \mathrm{kN} / \mathrm{m}^{3}$, and the average depth of the muddy clay is considered to be $8 \mathrm{~m}$ in the coastal area of Tianjin.

Combined with the experimental data [21] obtained for muddy soft clay in the coastal area of Tianjin, the values of the parameters $A, B$ and $T$ can be determined to be $3,05,0,805$ and 146 , respectively. The initial strain can be obtained based on a linear fitting using indoor creep test results. According to Eq. (15), for $t=5,7 \times 10^{8} \mathrm{~s}$, the long-term settlement data are as shown in Tab. 6 .

The long-term settlement in the coastal area of Tianjin is calculated to be $548 \mathrm{~mm}$. The sedimentation rate without external disturbance, such as constant consumption of groundwater or substantive construction of underground engineering, tends toward zero. The creep curve shows attenuation-stabilisation characteristics. The results of the calculated data agree well with the actual observation.

Table 6 Settlement calculation combining the modified Mesri model with the layer-wise summation method

\begin{tabular}{|c|c|c|c|c|c|c|c|c|c|}
\hline $\begin{array}{l}\text { Soil layer } \\
\text { thickness } \\
\text { /m }\end{array}$ & $\begin{array}{c}\sigma_{1} \\
/ \mathrm{kPa}\end{array}$ & $\begin{array}{c}\sigma_{3} \\
/ \mathrm{kPa}\end{array}$ & $\begin{array}{c}q \\
/ \mathrm{kPa}\end{array}$ & $\begin{array}{c}q_{f} \\
/ \mathrm{kPa}\end{array}$ & $D_{r}$ & $\begin{array}{c}\text { Initial } \\
\text { settlement / m }\end{array}$ & $\begin{array}{l}\text { Strain } \\
\varepsilon\end{array}$ & $\begin{array}{c}\text { Creep } \\
\text { settlement/m }\end{array}$ & $\begin{array}{c}\text { Sum of } \\
\text { settlement } \\
/ \mathrm{m}\end{array}$ \\
\hline 0,5 & 40,3 & 24,18 & 16,12 & 40,83 & 0,394 & 0,0153 & 0,0177 & 0,0088 & \\
\hline 0,5 & 49,3 & 29,58 & 19,72 & 46,69 & 0,422 & 0,0187 & 0,0195 & 0,0098 & \\
\hline 1 & 62,8 & 37,68 & 25,12 & 55,49 & 0,452 & 0,0239 & 0,0217 & 0,0218 & \\
\hline 1 & 80,8 & 48,48 & 32,32 & 67,22 & 0,480 & 0,0308 & 0,0239 & 0,0239 & \\
\hline 1 & 98,8 & 59,28 & 39,52 & 78,95 & 0,500 & 0,0376 & 0,0256 & 0,0256 & \\
\hline 1 & 116,8 & 70,08 & 46,72 & 90,68 & 0,515 & 0,0445 & 0,0269 & 0,0269 & \\
\hline 1 & 134,8 & 80,88 & 53,92 & 102,4 & 0,526 & 0,0513 & 0,0279 & 0,0279 & \\
\hline 1 & 152,8 & 91,68 & 61,12 & 114,1 & 0,535 & 0,0582 & 0,0287 & 0,0287 & \\
\hline 1 & 170,8 & 102,48 & 68,32 & 125,9 & 0,543 & 0,065 & 0,0295 & 0,0295 & 0,548 \\
\hline
\end{tabular}

\section{Conclusion}

The creep behaviour of typical soft clays in the coastal area of Tianjin was studied based on consolidated-undrained triaxial tests. Subsequently, a modified Mesri model with four parameters was established to predict the undrained creep behaviour. Each parameter has a definite physical meaning and can be obtained using the creep test. Finally, the modified model was verified by the test data and applied to calculation of the long-term settlement in the coastal area of Tianjin, the following conclusions may be drawn:

(1) The soft clays in the coastal area of Tianjin present distinct attenuation-steady state creep characteristics. With the increase of deviatoric stress, the creep effect becomes more obvious. The creep strain rate is not high in the steady state, and no significant constant-rate creep is observed.

(2) Soil deformation should be divided into two stages, one in which strain is caused by an increase in stress and one in which strain is caused by creep deformation. A modified Mesri model is established, which treats the final strain of the first-stage soil deformation as the initial strain and describes the second-stage soil deformation using a combination of a stress-strain hyperbolic function and strain-time hyperbolic function.

(3) The proposed creep model was compared with some test data and better prediction was achieved for modelling the creep strain of soft clays in the coastal area of Tianjin. The long-term settlement in the coastal area of Tianjin is calculated to be $548 \mathrm{~mm}$, which agrees well 
with the actual observation. The modified Mesri model can be well used to predict the creep behaviours of the typical soft clays in the coastal area of Tianjin.

\section{Acknowledgement}

This work was supported by the National Natural Science Foundation of China (ID 51279128).

\section{References}

[1] Kim, Y. T.; Leroueil, S. Modeling the viscoplastic behaviour of clays during consolidation: application to Berthierville clay in both laboratory and field conditions. // Canadian Geotechnical Journal. 38, 3(2001), pp. 484-497. https://doi.org/10.1139/t00-108

[2] Leroueil, S. The isotache approach. Where are we 50 years after its development by Professor Šuklje? // Proceedings of the 13th Danube-European Conference on Geotechnical Engineering / Ljubljana, 2006, pp. 55-88.

[3] Kim, D. K. A constitutive model with damage for cohesive soils. // KSCE Journal of Civil Engineering. 8, 5(2004), pp. 513-519. https://doi.org/10.1007/BF02899578

[4] Li, Y. S.; Zhao, C. J.; Zhao, L. P. Influence of bank soil creep deformation on high-piled wharf in Tianjin port. // China Harbour Engineering. 4(2009), pp. 5-8.

[5] Yin, Z. Y.; Chang, C. S.; Karstunen, M.; Hicher, P. Y. An anisotropic elastic-viscoplastic model for soft clays. // International Journal of Solids and Structures. 47, 5(2010), pp. 665-677. https://doi.org/10.1016/j.ijsolstr.2009.11.004

[6] Leoni, M.; Karstunen, M.; Vermeer, P. A. Anisotropic creep model for soft soils. // Géotechnique. 58, 3(2008), pp. 215-226. https://doi.org/10.1680/geot.2008.58.3.215

[7] Leoni, M.; Vermeer, P.; Karstunen, M. Validation of anisotropic creep model for soft soils. // Ground Improvement, 2nd International Workshop on Geotechnics of Soft Soils / Glasgow, 2009, pp. 165-171.

[8] Kelln, C.; Sharma, J.; Hughes, D.; Graham, J. An improved elastic-viscoplastic soil model. // Canadian Geotechnical Journal. 45, 10(2008), pp. 1356-1376. https://doi.org/10.1139/T08-057

[9] Luo, Q. Z.; Chen, X. P. Experimental research on creep characteristics of Nansha soft soil. // The Scientific World Journal. 2014, (2014). https://doi.org/10.1155/2014/968738

[10] Wang, Y. Z.; Wang, T. T.; Wang, J. A nonlinear rheological model of soft clay and its application to Tianjin littoral area. // Rock and Soil Mechanics. 30, 9(2009), pp. 2679-2685.

[11] Tian, S. Z.; Li, Y. S.; Ji, C. N. Creep test of soft clay for Tianjin Port. // Journal of Waterway and Harbor. 30, 6(2009), pp. 440-443.

[12] Yan, S. W.; Liu, K. J.; Li, W.; Hou, Y. M. Study of creep properties of soft clay in Tianjin Binhai New Area and no-yield-surface constitutive model. // Rock and Soil Mechanics, 31, 5(2010), pp. 1431-1436.

[13] Wang, Y. Z.; Huang, D. X.; Xiao, Z. Experimental research on creep properties of two typical soft clays in coastal region of Tianjin. // Journal of Geotechnical Engineering. 34, 2(2012), pp. 379-384.

[14] Mesri, G.; Rebres-Cordero, E.; Shields, D. R.; Castro, A. Shear stress-strain-time behaviour of clays. // Geotechnique, 31, 4(1981), pp. 537-552. https://doi.org/10.1680/geot.1981.31.4.537

[15] Sun, J. Creep of geometrical and its application. Chinese Construction Press, Beijing, 1999.

[16] Tan, T. K.; Kang, W. F. On the locked in stress, creep and dilatation of rocks, and the constitutive equations. //
Chinese Journal of Rock Mechanics and Engineering. 10, 4(1991), pp. 299-312.

[17] Yuan, J.; Gong, X. N.; Yi, D. Q. Comparison study on rheological constitutive models. // Chinese Journal of Rock Mechanics and Engineering. 20, 6(2001), pp. 772-779.

[18] Liu, Y. K.; Deng, Z. B.; Cao, P.; Huang, Y. H.; Lin, H. Triaxial creep test and modified Singh-Mitchell creep model of soft clay. // Journal of Central South University (Science and Technology). 43, 4(2012), pp. 1440-1446.

[19] Singh, A.; Mitchell, J. K. General stress-strain-time function for soils. // Journal of the Soil Mechanics and Foundations Division. 94, 1(1968), pp. 21-46.

[20] Вялов, С. С. Rheologic theory of soil mechanics. Science Press, Beijing, 1987.

[21] Wang, T. T. Study on the rheological model of littoral soft clay and its applications in the stability analysis of coastal structures (Ph.D. Thesis), Tianjin University, China, 2008.

\section{Authors' addresses}

\section{Ying Zhai, Dr}

Tianjin Key Laboratory of Port and Ocean Engineering, Tianjin University

No. 92 Weijin Road, Nankai District, Tianjin 300072, China tiffany_zy@tju.edu.cn

\section{Yuanzhan Wang, Prof.}

Tianjin Key Laboratory of Port and Ocean Engineering, Tianjin University

No. 92 Weijin Road, Nankai District, Tianjin 300072, China yzwang@tju.edu.cn

\section{Yanhe Dong}

Tianjin Key Laboratory of Port and Ocean Engineering, Tianjin University No. 92 Weijin Road, Nankai District, Tianjin 300072, China 407526870@qq.com 